\title{
Pengelolaan usaha tani bayam (Amaranthus tricolor L.) di Kota Pekanbaru
}

Fika Yulia Rachmah ${ }^{1}$, Sukendi ${ }^{2}$, Yusni Ikhwan Siregar ${ }^{2}$

\author{
${ }^{1}$ Mahasiswa Pascasarjana Ilmu Lingkungan Program Pascasarjana Universitas Riau. \\ ${ }^{2}$ Dosen Pascasarjana Ilmu Lingkungan Program Pascasarjana Universitas Riau.
}

\begin{abstract}
Spinach (Amaranthus tricolor L.) is a plant whose leaves are usually consumed as vegetables. The purpose of this study is to analyze spinach (A. tricolor L.) farming in an ecological, economic and social perspective and formulate sustainable spinach (A. tricolor L.) farming strategies in Pekanbaru City. The research was conducted in the city of Pekanbaru in May-July 2020. This research was conducted using the survey method to the field to obtain relevant information about the implementation of spinach farming in Pekanbaru City. The results of this study are the area of land for planting spinach in Tampan District covering 3 hectares and in Marpoyan Damai District 3.5 hectares. The type of soil used in Marpoyan Damai and Tampan Districts is humus soil. Soil pH in Marpoyan Damai and Tampan Districts ranges between 5.5-6. The average rainfall in Pekanbaru City is 170.7 with an average length of rainy days 14 days per month and humidity in Pekanbaru City is 70-85\%. Overall, in terms of ecology, it is suitable for good habitat for growing spinach. Costs incurred in Marpoyan Damai District are Rp 11,670,000 per hectare while in Tampan District $R p$ 8,260,000 per hectare. The revenue of spinach farming group in Marpoyan Damai District is Rp. 22,800,000 and in Tampan District is Rp. 17,100,000. The income of spinach farmers in Marpoyan Damai District is Rp11,130,000 and in Tampan District Rp8,840,000. B / C ratio in Marpoyan Damai District is 1.95 and in Tampan District is 2.07. In Marpoyan Damai Subdistrict, spinach farming is carried out by the Farmer Group, namely by Mr. Mudhofir who is 39 years old with high school education. Conflicts between farmers that have occurred are land problems and have been resolved as a family. In Tampan District, spinach farming is carried out by the Baskara Jati Farmer Group, namely by 51 -year-old Mr. Topan with junior high school education. Conflicts between farmers that have occurred are differences in understanding and have been resolved as a family. The management of spinach farming in Pekanbaru City has been going well, and there is already an efficiency in planting and it is said to be profitable. Based on this analysis, spinach farming in Pekanbaru City is profitable and feasible to be developed.
\end{abstract}

Keywords: Ecology; Economy; Socia; Spinach Farm Management

Bayam (Amaranthus tricolor L.) merupakan tanaman yang daunnya biasa dikonsumsi sebagai sayuran, karena memiliki tekstur yang lunak, kandungan seratnya pun cukup tinggi sehingga dapat membantu memperlancar proses pencernaan. Bayam kaya akan garam mineral seperti kalsium, fosfor, dan besi. Bayam juga mengandung beberapa macam vitamin, seperti vitamin A, B, dan C. Sayur ini juga mempunyai nilai ekonomis tinggi dibandingkan dengan beberapa jenis bayam lainnya. Hal ini disebabkan besarnya permintaan yang cukup tinggi dari beberapa supermarket, hotel dan restoran. Jika ditinjau dari aspek klimatologis, aspek teknis, aspek ekonomis dan aspek sosialnya Indonesia memiliki kelayakan dalam budidaya bayam. Bayam jika dipelihara dengan baik, dan syarat tumbuhnya terpenuhi, maka dapat diperoleh produksi 3,5-5 ton per hektar/tahun (Sunarjono, 2013 dan Tafajani, 2011).

Produksi bayam saat ini sangat berpotensi untuk dikembangkan baik kualitas dan kuantitasnya. Oleh karena itu diperlukan upaya baik dalam bidang peningkatan kualitas maupun kuantitas keamanan sayuran segar tersebut. Persoalan tersebut dapat ditanggulangi dengan konsep pengelolaan lingkungan hidup secara berkelanjutan. Konsep dasar tersebut memerlukan peranan pemerintah dan masyarakat secara langsung dalam implementasinya. Peranan pemerintah dan masyarakat merupakan suatu sumber daya besar yang memiliki keterkaitan terhadap masalah lingkungan. Sumber daya besar yang dimiliki oleh pemerintah dan masyarakat diperlukan suatu penghubung yang menjembatani kedua belah pihak. Penghubung tersebut berkaitan dengan sistem kelembagaan pertanian dalam masyarakat. Konsep pertanian berkelanjutan dapat dicapai dengan perencanaan wilayah berdasarkan setiap sumber daya alam di indonesia. Hasil SDA digunakan untuk memenuhi kebutuhan hidup manusia (Palar, 2008).

Usahatani merupakan suatu organisasi produksi, petani sebagai pelaksana untuk mengorganisasi tanah (alam), tenaga kerja dan modal yang ditujukan kepada produksi di lapangan pertanian baik yang didasarkan atas pencaharian laba atau tidak. Usahatani dikatakan berhasil apabila usahatani tersebut dapat menghasilkan pendapatan untuk membayar semua biaya dan alat yang diperlukan, dengan kata lain keberhasilan suatu usahatani berkaitan erat dengan pendapatan dan biaya yang dikeluarkan. Kemampuan 
menghasilkan produk pertanian pangan ditentukan oleh berbagai faktor, termasuk biofisik, sosial, ekonomi dan politik (Rumajar, 2010).

Pelaksanaan proses produksi pada suatu usahatani, petani dihadapkan pada masalah intern dan ekstern, masalah intern diantaranya keterbatasan faktor produksi, baik kualitas maupun kuantitas. Dengan demikian petani harus pandai memilih dan mengkoordinasikan jenis-jenis tanaman yang menguntungkan serta mengkombinasikan faktor produksi yang ada sehingga dapat menghasilkan pendapatan yang maksimal. Sedangkan masalah ekstern adalah kondisi alam atau musim serta serangan hama dan penyakit.

Jumlah produksi bayam di Kota Pekanbaru yaitu 411 ton pada tahun 2017 dan meningkat menjadi 1.908 ton pada tahun 2019. Bayam dipilih sebagai objek penelitian karena bayam termasuk sayuran hijau yang banyak diminati masyarakat Pekanbaru. Bayam juga banyak tumbuh di daerah tropik seperti Kota Pekanbaru, di pinggir-pinggir jalan parit dan sudut jalan di Kota Pekanbaru banyak para petani yang menanam sayur-sayuran, seperti sayur bayam, kangkung, sawi, selada, jagung dan sayuran hijau lainnya. Berdasarkan uraian di atas, maka penulis tertarik untuk meneliti pengelolaan usaha tani bayam (A.tricolor L.) di Kota Pekanbaru.

\section{METODE PENELITIAN}

Penelitian ini dilaksanakan di Kecamatan Marpoyan Damai dan Kecamatan Tampan Kota Pekanbaru dari bulan Mei-Juli 2020. Pendekatan penelitian ini adalah metode survei. Jenis data yang digunakan yaitu data berkenaan dengan budidaya bayam (A. tricolor L.) dan usahatani bayam berupa data sekunder mengenai ekologi pertanian bayam yang terdiri dari luas lahan, jenis tanah, $\mathrm{pH}$ tanah, curah hujan dan kelembaban. Data sekunder diperoleh melalui penghimpunan informasi berkenaan dengan budidaya bayam dari Dinas Pertanian Kota Pekanbaru, selain itu data dan informasi juga diperoleh dari serta Badan Meteorologi, Klimatologi dan Geofisika (BMKG) Kota Pekanbaru. Data berkenaan dengan budidaya bayam (A. tricolor L.) dan usahatani bayam berupa data primer untuk mendapatkan data ekonomi dan sosial. Data ekonomi terdiri dari jumlah biaya, penerimaan, pendapatan serta efisiensi usaha. Data sosial petani berupa usia petani, pendidikan, tenaga kerja, lahan yang digunakan, konflik antar petani serta pola tanam. Analisis data dilakukan dengan analisis ekologi, ekonomi dan sosial.

\section{HASIL DAN PEMBAHASAN}

\section{Aspek Ekologi Usahatani Bayam (A. Tricolor L.)}

\section{Luas Lahan}

Berdasarkan hasil wawancara yang dilakukan dengan salah satu petani bayam di Jalan Rawa Bening, Kelurahan Sidomulyo Barat Kecamatan Tampan diketahui bahwa luas lahan yang dikelolanya untuk menanam bayam adalah 3 hektar. Sedangkan hasil wawancara dengan salah satu petani bayam di Jalan Kartama Kecamatan Marpoyan Damai diketahui bahwa luas lahan untuk pertanian bayam adalah 3,5 hektar seperti pada Tabel 1:

Tabel 1. Luas Lahan

\begin{tabular}{ll}
\hline \multicolumn{1}{c}{ Kecamatan } & Luas Lahan \\
\hline Marpoyan Damai & 3,5 hektar \\
Tampan & 3 hektar \\
\hline Sumber: Data Primer, 2020
\end{tabular}

Lahan atau tanah merupakan tempat tumbuh tanaman, tanah sebagai harta produktif adalah bagian organisasi rumah tangga tani. Luas lahan pertanian menentukan penghasilan, taraf hidupnya dan derajat kesejahtraan rumah tangga tani. Tanah berkaitan erat dengan keberhasilan usaha tani dan teknologi modern yang digunakan untuk mencapai keuntungan usaha tani. Menurut Rosyidi (2009) Lahan maupun sumber daya alam disini adalah segala sumber asli yang tidak berasal dari kegiatan manusia yang bisa diperjual belikan, Lahan merupakan faktor produksi sangat penting dalam usaha tani di negara-negara yang sedang berkembang.

Sebagian petani rata-rata memiliki lahan yang cukup untuk menanam bayam. Luas lahan pertanian merupakan suatu usaha tani ukuran luas lahan secara tradisional perlu dipahami agar dapat mengetahui ukuran luas lahan yang dinyatakan dengan hektar. Disamping ukuran luas lahan maka ukuran nilai tanah juga diperhatikan (Soekartawi, 2002).

Bayam tidak membutuhkan lahan yang luas untuk dapat menanamnya dalam jumlah besar. Lahan untuk pertanaman bayam perlu diolah lebih dahulu dengan dicangkul sedalam 20-30 cm supaya gembur. 
Setelah itu dibuat bedengan dengan arah membujur dari Barat ke Timur, untuk mendapatkan cahaya penuh. Lebar bedengan $1 \mathrm{~m}$, sedangkan panjang bedengan dapat dibuat tergantung ukuran/bentuk lahan.

Usaha tani misalnya kepemilikan lahan yang sempit pertanian semakin tidak efisien usaha tani yang dikelolanya kecuali bila usaha tani tersebut dikelola dengan baik. Luas kepemilikan lahan berhubungan dengan penggunaan lahan secara efisian yang akan berpengaruh terhadap peningkatan hasil produksi. Jika luas lahan yang dimiliki semakin luas maka semakin besar produksi yang dihasilkan kecuali bila suatu usaha tani dijalankan dengan baik dan administrasi yang baik serta teknologi yang tepat (Suratiyah, 2015).

\section{Jenis Tanah}

Berdasarkan hasil pengambilan data oleh Dinas Pertanian Kota Pekanbaru (2020), jenis tanah di Jalan Rawa Bening, Kelurahan Sidomulyo Barat adalah tanah organosol dan di Jalan Kartama Kecamatan Marpoyan Damai diketahui bahwa jenis tanah untuk pertanian bayam juga merupakan tanah organosol.

Tanah organosol merupakan tanah yang proses pembentukannya dari hasil pembusukkan bahanbahan organik. Tanah organosol ini biasanya dapat ditemui di daerah rawa- rawa atau di tempat- tempat yang selalu tergenang oleh air. Tanah organosol ini merupakan tanah yang sangat lembab bahkan bisa dikatakan becek karena keberadaannya di sekitar lingkungan berair. Tanah organosol terbagi menjadi tanah humus dan tanah gambut. Tanah humus merupakan tanah yang biasanya digunakan sebagai lahan pertanian. Ciri-ciri tanah humus yaitu berwarna kehitaman, mudah basah, sangat subur dan banyak mengandung bahan organik.

Bayam cocok ditanam pada hampir setiap jenis tanah dan dapat tumbuh sepanjang tahun pada ketinggian sampai dengan $1000 \mathrm{~m}$ dpl. Penggunaan tanah humus pada penanaman bayam sudah sangat tepat karena tanah humus juga mengandung banyak bahan organik. Jika tanah yang digunakan kurang mengandung bahan organik, lahan untuk menanam bayam perlu ditambahkan lagi dengan pupuk.

\section{pH Tanah}

Berdasarkan hasil pengambilan data oleh Dinas Pertanian Kota Pekanbaru (2020), pH tanah di Jalan Rawa Bening, Kelurahan Sidomulyo Barat dan di Jalan Kartama Kecamatan Marpoyan Damai adalah 5,5-6. Bayam dapat tumbuh dengan baik di tanah rata-rata, tetapi akan tumbuh subur di tanah yang kaya akan bahan organik. Secara umum, jenis dan $\mathrm{pH}$ tanah jarang menjadi faktor pembatas ketika menanam bayam. Menurut Pracaya (2007) produktivitas bayam merah dapat meningkat jika ditanam pada kondisi lahan dengan kandungan bahan organik yang tinggi, ketersediaan unsur hara nitrogen yang tinggi dan memiliki kisaran $\mathrm{pH}$ 6-7.

\section{Curah Hujan}

Curah hujan di Kota Pekanbaru pada Tahun 2019 dapat dilihat pada Tabel 2:

Tabel 2. Curah Hujan di Kota Pekanbaru Tahun 2019

\begin{tabular}{|c|c|c|}
\hline Bulan & Curah Hujan (mm) & Lama Hari Hujan \\
\hline Januari & 139,9 & 16 \\
\hline Februari & 34,4 & 9 \\
\hline Maret & 356,5 & 21 \\
\hline April & 129,3 & 19 \\
\hline Mei & 140,1 & 15 \\
\hline Juni & 103,6 & 13 \\
\hline Juli & 13,5 & 5 \\
\hline Agustus & 277,8 & 10 \\
\hline September & 60 & 7 \\
\hline Oktober & 64,7 & 11 \\
\hline November & 411,4 & 22 \\
\hline Desember & 317,1 & 25 \\
\hline JUMLAH & 2048,3 & 173 \\
\hline RATA-RATA & 170,7 & 14,42 \\
\hline
\end{tabular}

Sumber: Dinas Pertanian Kota Pekanbaru, 2019

Berdasarkan data dari Dinas Pertanian Kota Pekanbaru, diketahui bahwa rata-rata curah hujan di Kota Pekanbaru adalah 170,7 dengan rata-rata lama hari hujan 14 hari setiap bulannya. Curah hujan adalah jumlah air yang jatuh di permukaan tanah datar selama periode tertentu yang diukur dengan satuan tinggi $(\mathrm{mm})$ di atas permukaan horizontal bila tidak terjadi evaporasi, run off dan infiltrasi. Satuan $\mathrm{CH}$ adalah $\mathrm{mm}$, inch. terdapat beberapa cara mengukur curah hujan. Curah hujan (mm) : merupakan ketinggian air hujan yang terkumpul dalam tempat yang datar, tidak menguap, tidak meresap, dan tidak mengalir. Curah hujan 1 (satu) millimeter, artinya dalam luasan satu meter persegi pada tempat yang datar 
tertampung air setinggi satu millimeter atau tertampung air sebanyak satu liter. Curah hujan kumulatif $(\mathrm{mm})$ : merupakan jumlah hujan yang terkumpul dalam rentang waktu kumulatif tersebut. Dalam periode musim, rentang waktunya adalah rata-rata panjang musim pada masing-masing Daerah Prakiraan Musim (DPM) (Siregar, 2005).

\section{Kelembaban}

Berdasarkan data dari Dinas Pertanian Kota Pekanbaru, diketahui bahwa kelembaban di Kota Pekanbaru tahun 2019 adalah $70-85 \%$. Dalam proses penanamannya, kesuburan bayam sangat dipengaruhi sekali oleh kesuburan tanah, suhu dan kelembaban. Kelembaban yang dibutuhkan untuk menanam bayam yaitu kelembaban di atas $60 \%$.

Kelembaban udara menggambarkan kandungan uap air di udara yang dapat dinyatakan sebagai kelembaban multak, kelembaban nisbi, maupun defisit tekanan uap air. Kelembaban relatif adalah perbandingan antara masa uap air yang ada di dalam satu satuan volume udara, dengan masa uap air yang maksimum dapat dikandung pada suhu dan tekanan yang sama. Kelembaban udara erat hubungannya dengan ketersediaan air. Saat kelembaban terlalu tinggi, seluruh pori-pori tanah akan terisi air hingga titik jenuh. Pada siang hari kelembaban udara menurun hingga $45-50 \%$ hal ini disebabkan intensitas radiasi matahari siang hari relatif lebih besar yang mengenai secara langsung pada tanaman. Pada sore hari, kelembaban udara memiliki persentasi yang hampir sama dengan kelembaban udara pada pagi namun lebih tinggi dibandingkan dengan kelembaban udara pada siang hari yaitu berkisar antara $75-85 \%$ (Cahyadi, 2006).

\section{Rentabilitas Usahatani Bayam (A. Tricolor L.)}

\section{Analisis Biaya}

Untuk mengetahui berapa besar biaya produksi yang dikeluarkan dalam usahatani tanaman bayam dengan melakukan perhitungan biaya yang dikeluarkan untuk masing-masing input. Biaya produksi dapat terdiri dari bibit, obat-obatan, pupuk serta tenaga kerja.

Berdasarkan hasil wawancara yang telah dilakukan pada kelompok tani Suka Makmur, yaitu kelompok tani yang berada di Jalan Kartama Kecamatan Marpoyan Damai diketahui bahwa biaya-biaya yang dikeluarkan dapat dilihat pada Tabel 3:

Tabel 3. Analisis Biaya yang Dikeluarkan Kelompok Usahatani Bayam per Hektar di Kota Pekanbaru

$$
\text { Biaya Kecamatan Marpoyan Damai } \quad \text { Kecamatan Tampan }
$$

$\begin{array}{lcc}\text { Biaya Tetap } & & \\ \text { Biaya penyusutan alat } & \mathrm{Rp} 40.000 & \mathrm{Rp} 50.000 \\ \text { Upah tenaga kerja } & \mathrm{Rp} 3.600 .000 & - \\ \text { Iuran anggota } & \mathrm{Rp} 10.000 / \text { bulan } & 10.000 / \text { bulan } \\ \text { Biaya Tidak Tetap } & & \\ \text { Bibit } & \mathrm{Rp} 520.000 & \mathrm{Rp} 800.000 \\ \text { Pupuk kandang } & \mathrm{Rp} 7.500 .000 & \mathrm{Rp} 6.800 .000 \\ \text { Insektisida } & - & \mathrm{Rp} 600.000 \\ \text { Total } & \mathrm{Rp} 11.670 .000 & \mathrm{Rp} 8.260 .000\end{array}$

Sumber: Data Primer, 2020

Berdasarkan Tabel 3 dapat dilihat bahwa biaya penyusutan alat sebesar Rp 40.000 di Kecamatan Marpoyan Damai dan Rp 50.000 di Kecamatan Tampan. Di Kecamatan Marpoyan Damai menggunakan tenaga kerja pada saat panen yang dibayar dengan Rp 150 per ikat bayam yang dipanen. Dengan asumsi bahwa bayam yang didapat sebanyak 400 ikat per bedeng dan dalam 1 hektar terdapat 60 bedeng, maka biaya tenaga kerja yang dikeluarkan adalah Rp 3.600.000. Sedangkan di Kecamatan Tampan, tenaga kerja yang digunakan dibayar dengan berbagi hasil panen. Iuran anggota pada kedua kelompok tani adalah sama, yaitu masing-masing Rp 10.000/bulan.

Biaya bibit yang digunakan yaitu di Kecamatan Marpoyan Damai sebesar Rp 520.000 dan di Kecamatan Tampan sebesar Rp 800.000. Biaya pupuk yang digunakan yaitu di Kecamatan Marpoyan Damai sebesar Rp 7.500.000 dan di Kecamatan Tampan sebesar Rp 6.800.000. Di Kecamatan Marpoyan 
Damai tidak menggunakan insektisida namun menggunakan daun katuk (Sauropus androgynus) sebagai gantinya. Sedangkan di Kecamatan Tampan, biaya yang dikeluarkan untuk insektisida yaitu sebesar Rp 600.000 .

Berdasarkan Tabel 3 dapat dilihat bahwa biaya yang dikeluarkan di Kecamatan Marpoyan Damai lebih besar, yaitu Rp 11.670.000 per hektar sedangkan di Kecamatan Tampan sebesar Rp 8.260.000 per hektar. Perbedaan biaya terbesar terletak di pembayaran tenaga kerja, karena di Kecamatan Tampan, tenaga kerja dibayar dengan pembagian hasil panen.

Analisis biaya adalah salah satu teknis yang digunakan untuk mengevaluasi penggunaan sumbersumber ekonomi agar dapat digunakan secara efisien. Analisis biaya merupakan alat bantu untuk membuat keputusan, dengan mempertimbangkan sejauhmana sumberdaya yang digunakan (sebagai biaya) dapat memberikan hasil-hasil yang diinginkan (manfaat) secara optimal. Analisis biaya digunakan manakala hal efisiensi secara akurat dan rasional menjadi pertimbangan utama (Rosyidi, 2009).

Biaya total cenderung disebut juga dengan modal. Modal yang diperlukan untuk mendirikan atau menjalankan suatu usaha untuk membiayai segala keperluan usahatani mulai dari biaya produksi sampai dengan biaya-biaya yang lain selama proses, pengelolaan sampai menghasilkan produksi bayam (Noor, 2007). Modal diartikan sumber dana jangka panjang ada dalam perusahaan, terdiri modal sendiri (equity) dan utang jangka panjang.

Modal didalam usahatani merupakan salah satu faktor produksi yang digunakan untuk menghasilkan produksi, produksi dapat di tingkatkan dengan menggunakan alat-alat tani dan cara pengelolaan yang efesien. Dalam proses produksi tidak ada perbedaan antara modal sendiri dengan modal pinjaman yang masing-masing juga berperan langsung untuk menghasilkan produksi yang di harapkan oleh petani (Indriantoro, 2002).

Menurut Daniel (2005) modal produksi juga dapat artikan yaitu biaya yang keluarkan oleh seseorang untuk dapat menghasilkan output. Modal produksi terdiri dari dua kategori yaitu modal tetap dan modal bergerak. Modal tetap adalah barang-barang yang digunakan dalam proses produksi yang dapat digunakan beberapa kali, meskipun akhirnya barang-barang itu habis juga contohnya mesin, pabrik, peralatan tani dan lain-lainnya. Sedangkan modal bergerak yaitu barang yang digunakan dalam proses produksi yang hanya biasa digunakan untuk sekali pakai misalnya pupuk, bibit, obat-obatan dan yang lainlain (Mankiw, 2003).

Berdasarkan penelitian oleh Dharman (2013), rata-rata biaya produksi usaha tani bayam sampel per 4,2 rante di Desa Hamparan Perak tahun 2013 yaitu $\mathrm{Rp} 2.988 .114,86$ dengan persentase biaya terbesar ada di pembayaran tenaga kerja sebesar $57,45 \%$. Sedangkan biaya yang paling sedikit yaitu biaya penyusutan alat $\operatorname{Rp} 36.134,29$ atau $1,21 \%$.

\section{Analisis Penerimaan}

Analisis penerimaan digunakan untuk mengetahui besarnya penerimaan yang diterima oleh produsen usahatani tanaman bayam. Berdasarkan hasil wawancara yang telah dilakukan pada kelompok tani Suka Makmur, yaitu kelompok tani yang berada di Jalan Kartama Kecamatan Marpoyan Damai diketahui bahwa penerimaan usahatani bayam dapat dilihat pada Tabel 4.

Tabel 4. Analisis Penerimaan Kelompok Usahatani Bayam per Hektar di Kota Pekanbaru

\begin{tabular}{lcc}
\hline \multicolumn{1}{c}{ Biaya } & Kecamatan Marpoyan Damai & Kecamatan Tampan \\
\hline Harga & Rp 950 & Rp 950 \\
Jumlah Produksi per bedeng & 400 ikat & 450 ikat \\
Jumlah bedeng & 60 & 40 \\
\hline Penerimaan Total & Rp 22.800.000 & Rp 17.100.000 \\
\hline
\end{tabular}

Sumber: Data Primer, 2020

Berdasarkan hasil perhitungan yang telah dilakukan, penerimaan kelompok usaha tani bayam di Kecamatan Marpoyan Damai lebih besar dibandingkan Kecamatan Tampan, yaitu Rp 22.800 .000 di Kecamatan Marpoyan Damai dan di Kecamatan Tampan sebesar Rp 17.100.000. Selisih penerimaan yang cukup besar ini dapat diakibatkan karena di Kecamatan Tampan, hasil produksi seharusnya 500-600 ikat per bedeng, namun sebagian diberikan untuk tenaga kerja sehingga jumlah produksi rata-rata per bedeng menjadi 450 ikat.

Penerimaan merupakan jumlah produk yang dihasilkan dalam produksi dikalikan dengan harga jual produk. Berdasarkan hasil penelitian oleh Kamisi (2013), tiap-tiap produsen usahatani bayam di Kelurahan Sasa Kecamatan Ternate Selatan mempunyai penerimaan yang menguntungkan karena penerimaan lebih besar dari pada biaya produksi. Penerimaan usahatani bayam di Kelurahan Sasa Kecamatan Ternate 
Selatan dapat dijelaskan sebagai berikut : Total penerimaan sebesar Rp. 40.500.000, yaitu sebagai berikut; bayam merah sebanyak 60 petak dan menghasilkan 3000 ikat dengan nilai jual per ikat sebesar Rp. 6000, sehingga bayam merah mendapatkan penerimaan sebesar Rp. 18.000.000. Sedangkan bayam hijau sebanyak 90 petak dan menghasilkan 4500 ikat dengan nilai jual per ikat sebesar Rp. 5000, sehingga bayam hijau mendapatkan penerimaan sebesar Rp. 22.500.000.

\section{Analisis Pendapatan}

Untuk menganalisis pendapatan yang diperoleh pengusaha alam memproduksi bayam, maka dapat digunakan analisis yang dikemukakan oleh Mosher (1998) yaitu pendapatan merupakan penerimaan total dikurangi biaya total. Berdasarkan hasil wawancara yang telah dilakukan pada kelompok tani Suka Makmur, yaitu kelompok tani yang berada di Jalan Kartama Kecamatan Marpoyan Damai diketahui bahwa pendapatan yang diterima dapat dilihat pada Tabel 5 .

Tabel 5. Analisis Pendapatan Kelompok Usahatani Bayam di Kota Pekanbaru

\begin{tabular}{ccc}
\hline Biaya & Kecamatan Marpoyan Damai & Kecamatan Tampan \\
\hline Penerimaan & Rp 22.800.000 & Rp 17.100.000 \\
Biaya Produksi & $\mathrm{Rp} \mathrm{11.670.000}$ & $\mathrm{Rp} \mathrm{8.260.000}$ \\
\hline Pendapatan & $\mathrm{Rp} \mathrm{11.130.000}$ & $\mathrm{Rp} \mathrm{8.840.000}$ \\
\hline Sumber: Data Primer, 2020 & &
\end{tabular}

Berdasarkan hasil penelitian yang dilakukan, diketahui bahwa pendapatan petani bayam di Kecamatan Marpoyan Damai yaitu sebesar Rp 11.130.000 dan di Kecamatan Tampan sebesar Rp 8.840.000.

Pendapatan atau keuntungan akan didapat setelah mengetahui nilai biaya dan nilai penerimaan. Menurut penelitian Kamisi (2013) diketahui bahwa pendapatan produksi usahatani tanaman bayam di Kelurahan Sasa Kecaamtan Ternate Selatan sebesar Rp 24.095.000 untuk sekali produksi. Penelitian oleh Dharma (2013) menyatakan bahwa pendapatan adalah penerimaan usahatani bayam setelah dikurangi dengan biaya produksi yang dikeluarkan petani dalam menghasilkan bayam. Pendapatan dihitung dalam rupiah per musim tanam. Dari hasil penelitian Dharma (2013) pendapatan usahatani bayam yang diperoleh petani sampel berkisar antara Rp. 2.935.800,00 - Rp 13.113.900,00 dengan pendapatan rata-rata Rp. 7.457.885,14.

\section{Analisis Efisiensi Usaha}

Untuk mengukur tingkat efisiensi usaha dalam proses produksi usahatani tanaman bayam digunakan analisis $\mathrm{B} / \mathrm{C}$ ratio. Analisis $\mathrm{BC}$ ratio digunakan untuk mengetahui tingkat efisiensi usahatani tanaman bayam secara finansial. Efisiensi usahatani tanaman bayam bisa ditentukan dengan menghitung per cost ratio yaitu pembagian antara penerimaan suatu usaha dengan total biaya produksi. Besarnya penerimaan dan produksi yang harus dicapai agar petani memperoleh keuntungan, serta harga jual yang menentukan apakah petani mendapat keuntungan dari total biaya produksi yang telah dikeluarkan Hasil pengukuran tingkat efisiensi usaha dalam proses produksi usahatani tanaman bayam digunakan analisis B/C ratio dapat dilihat pada Tabel 6 .

Tabel 6. Analisis Efisiensi Usaha Kelompok Usahatani Bayam di Kota Pekanbaru

\begin{tabular}{ccc}
\hline Biaya & Kecamatan Marpoyan Damai & Kecamatan Tampan \\
\hline Penerimaan total (TR) & Rp 22.800.000 & Rp 17.100.000 \\
Biaya total (TC) & Rp 11.670.000 8.260 .000 \\
\hline BC Ratio & 1,95 & 2,07 \\
\hline Sumber: Data Primer, 2020 & &
\end{tabular}

Berdasarkan hasil penelitian yang dilakukan, diketahui bahwa BC/Ratio petani bayam di Kecamatan Marpoyan Damai dan di Kecamatan Tampan $>1$. Hal ini berarti usaha tani bayam di Kecamatan Marpoyan Damai dan di Kecamatan Tampan efisiensi dan menguntungkan untuk diusahakan.

Hasil penelitian oleh Dharma (2014) didapatkan B/C ratio sebesar 3,51 dengan kata lain setiap Rp 1 yang dikeluarkan akan menghasilkan penerimaan sebesar Rp 3,51. Pada penelitian oleh Kamisi (2013) nilai $\mathrm{B} / \mathrm{C}$ rasio usahatani tanaman bayam sebesar 2,4687 . Ini menandakan usahatani tersebut efisien dan menguntungkan sehingga layak dikembangkan.

\section{Analisis Sosial Usahatani Bayam (A. Tricolor L.)}

Berdasarkan hasil wawancara di Jalan Kartama Kecamatan Marpoyan Damai, pertanian bayam dilakukan oleh Kelompok Tani Suka Makmur, yaitu oleh Bapak Mudhofir yang berusia 39 tahun. Berdasarkan hasil wawancara di Jalan Rawa Bening Kecamatan Tampan, pertanian bayam dilakukan oleh Kelompok Tani Baskara Jati, yaitu oleh Bapak Topan yang berusia 51 tahun. 
Berdasarkan hasil wawancara di Jalan Kartama Kecamatan Marpoyan Damai, pertanian bayam dilakukan oleh Kelompok Tani Suka Makmur, yaitu oleh seorang petani dengan pendidikan terakhir SMA. Berdasarkan hasil wawancara di Jalan Rawa Bening Kecamatan Tampan, pendidikan terakhir petani adalah SMP.

Berdasarkan hasil wawancara di Jalan Kartama Kecamatan Marpoyan Damai, pertanian bayam dilakukan oleh tenaga kerja sendiri, namun terkadang memakai upah tenaga kerja lain saat sedang panen. Tenaga kerja tersebut memiliki kegiatan yaitu setiap seminggu sekali dilakukan rapat kelompok. Upah tenaga kerja tersebut adalah Rp150 untuk per ikat bayam yang dipanen.

Berdasarkan hasil wawancara di Jalan Rawa Bening Kecamatan Tampan, jumlah tenaga kerja yang digunakan adalah 18 orang tenaga kerja, yaitu 11 orang wanita dan 7 orang pria. Pekerjaan pria adalah menggemburkan tanah, menanam, memupuk, menyiram dan menyemprot jika terdapat hama. Pekerjaan tenaga kerja wanita adalah memanen dan memasarkan. Biaya yang dikeluarkan untuk tenaga kerja tersebut biasa dibagikan berupa hasil panen, jarang berupa uang karena sistemnya gotong royong.

Tenaga kerja dalam sebuah usaha tani cukup berperan untuk mendukung aktifitas usaha tersebut dilihat dari fungsi produksi suatu usaha tenaga kerja merupakan salah satu faktor yang dapat menghasilkan produksi secara optimal dan skill sangat di perlukan dalam pengelola usaha pertanian. Sutrisno (2006) Menjelaskan bahwa tenaga kerja salah satu unsur penentu terutama bagi usaha tani yang sangat tergantung, kelangkaan tenaga kerja berakibat mundurnya penanaman sehingga berpengaruh pada pertumbuhan tanaman dan kualitas produksinya. Bahwa faktor tenaga kerja sangat di butuhkan dalam proses kegiatan produksi walaupun tenaga kerja berasal dari keluarga sendiri. Jika tenaga kerja tidak ada maka berdampak kepada jumlah produksi dalam usaha tani bayam.

Berdasarkan hasil wawancara di Jalan Kartama Kecamatan Marpoyan Damai, pertanian bayam dilakukan di lahan pinjam. Lahan ini termasuk ke dalam tanah pemakaman. Lahan pertanian seluas 3,5 hektar ini terbentuk sejak tahun 1998, tetapi kelompok pertanian itu sendiri terbentuk sejak tahun 2008 . Hasil pertanian yang ditanam di lahan ini yaitu kangkung, sawi serta bayam. Kepemilikan lahan dipinjamkan oleh pemerintah setempat yaitu Kelurahan Maharatu Kecamatan Marpoyan Damai. Petani diberi kepercayaan untuk mengelola lahan tanpa dipungut biaya/sewa lahan.

Berdasarkan hasil wawancara di Jalan Rawa Bening Kecamatan Tampan, lahan digunakan adalah lahan milik pribadi dan sebagian milik orang. Namun tidak ada biaya sewa lahan atau bagi hasil, hanya disuruh merawat lahan saja. Lahan pertanian ini sudah terbentuk sejak tahun 2005 dengan rincian 1,5 Ha milik pribadi dan 1,5 Ha milik orang. Yang ditanam di lahan ini yaitu bayam, kangkung, kacang tanah, timun, sawi, selada, cabai.

Lahan merupakan sarana produksi bagi usahatani, termasuk salah satu faktor produksi dan pabrik hasil pertanian. Lahan adalah sumberdaya alam fisik yang mempunyai peranan sangat penting bagi petani (Mosher, 1968). Lion Berger dalam Mardikanto (1993) penguasaan lahan yaitu luas lahan yang diusahakan. Luas sempitnya lahan berpengaruh pada sistem pertanian yang dilakukan. Petani dengan kepemilikan lahan yang rata-rata luas akan lebih mudah menerima perubahan dalam sistem usahatani. Biasanya semakin luas lahan yang dimiliki maka semakin cepat dalam mengadopsi karena memiliki kemampuan ekonomi lebih baik.

Status kepemilikan lahan yang beragam akan mempengaruhi karakteristik - karakteristik antara lain : Jaminan akses untuk jangka panjang, kemudahan membuat keputusan berkaitan dengan pemanfaatan lahan, kemudahan ikut serta dalam pembentukan kelompok, kemudahan pemerintah dalam campur tangan penyuluhan, bantuan kredit, maupun investasi langsung (Pakpahan, 1992). Dengan demikian status kepemilikan lahan sangat berpengaruh terhadap efektivitas petani dalam menerima suatu inovasi.

Berdasarkan hasil wawancara di Jalan Kartama Kecamatan Marpoyan Damai, diketahui bahwa pernah terjadi konflik pada tahun 2009 dengan petani lainnya. Karena lahan tersebut dipinjamkan oleh pemakaman umum sehingga ada petani lain yang ingin ikut menggarap di lahan ini. Namun masalah tersebut sudah lama selesai dan diselesaikan secara kekeluargaan.

Berdasarkan hasil wawancara di Jalan Rawa Bening Kecamatan Tampan, konflik antar petani pernah terjadi namun hanya berupa selisih paham saja dan sudah lama terselesaikan. Cara penyelesaiannya menggunakan cara kekeluargaan. Berdasarkan hasil wawancara di Jalan Kartama Kecamatan Marpoyan Damai, diketahui bahwa tumbuhan yang ditanam di lahan ini adalah kangkung, bayam merah dan bayam hijau, serta sawi. Bayam diproduksi setiap 20 hari. Bayam hasil produksi langsung dijual ke konsumen namun sebagian juga ada ke tengkulak. Bibit untuk menanam bayam dibeli di toko pertanian dengan harga Rp 65.000/kg. Penggunaan bibit yaitu sebanyak 5 sendok makan untuk ukuran bedengan $3 \times 20$ meter. Pupuk yang digunakan yaitu pupuk kandang. Pupuk yang digunakan yaitu 


\section{ZONA}

Jurnal Lingkungan

ISSN : 2502-6496 (Print)

sebanyak 150 karung dengan berat 1 karung nya 50 kg. Petani di Jalan Kartama Kecamatan Marpoyan Damai tidak menggunakan insektisda.

Langkah petani dalam menanam bayam yaitu awalnya tanah digemburkan, setelah itu diratakan. Untuk ukurang tanah bedengan dibuang $20 \times 3$ meter. Setelah diratakan, dicampurkan dengan pupuk kandang dengan cara ditaburkan pupuknya dicampurkan dengan tanah. Setelah ditabur pupuk kandang baru ditebar benih (dicampurkan tanah dan benih biar merata). Menjelang tumbuh akan dilakukan penyiraman 3 hari pertama berturut turut sebanyak 2 kali sehari (pagi dan sore). Petani tidak menggunakan pupuk urea dan hanya menggunakan pupuk kandang. Petani juga tidak menggunakan pestisida, karna untuk di lahan pada tanaman bayam memang jarang sekali terserang hama karna petani sudah mencegahnya dengan menanam tanaman refugia.

Tanaman refugia yang ditanam yaitu daun katuk (Sauropus androgynus) (Sauropus androgunus L. Merr). 10 - 15 hari sebelum petani menanam bayam, petani sudah lebih dulu menanam tanaman katuk (Sauropus androgynus), pertama gemburkan bedengan tanah yang ukuran $3 \times 20$ meter dan petani hanya menanam tanaman katuk (Sauropus androgynus) di sekeliling pinggiran tanah bedengan tadi seluas setengah meter dengan kedalaman tanah untuk menanam $20 \mathrm{~cm}$ dan jarak tanam $20 \times 20 \mathrm{~cm}$ dan sejajar. Batang tanaman katuk (Sauropus androgynus) ditancapkan dengan tegak lurus sekeliling bedengan. Penyiraman dilakukan secara berkala pagi dan sore. Minimal 2x dalam seminggu setelah tumbuh tunasnya dilakukan penyiangan setelah katuk (Sauropus androgynus) mulai menginjak 15 hari, tepat disaat petani mulai menanam bayam. Selanjutnya daun katuk (Sauropus androgynus) bisa disiangi sebulan sekali dan tanaman daun katuk (Sauropus androgynus) bisa di panen diumur 3- 3,5 bulan dengan tinggi tanaman katuk (Sauropus androgynus) kurang lebih sudah $70 \mathrm{~cm}$. Waktu panen katuk (Sauropus androgynus) dilakukan pada pagi dan sore hari.

Di Jalan Kartama Kecamatan Marpoyan Damai, petani tidak menggunakan pestisida. Daun katuk (Sauropus androgynus) sudah ditanam sebagai tanaman pengendali hama atau yang sering disebut tanaman refugia. Pada tanaman bayam, hama yang sering menempel adalah ulat daun dan kumbang, jadi dengan menanam daun katuk (Sauropus androgynus) sayur bayam tidak akan terkena hama lagi karena sudah ada tanaman lain yang menjadi tempat persinggahan serangga. Pemilihan daun katuk (Sauropus androgynus) karena selain ekonomis juga ramah lingkungan, perawatannya mudah serta mempunyai nilai komersil, sehingga petani juga bisa mendapatkan keuntungan dari memanen daun katuk (Sauropus androgynus).

Petani di di Jalan Kartama Kecamatan Marpoyan Damai bisa menanam bayam 9 hingga 10 kali tanam dalam setahun. Dalam setahun ada waktu petani mengistirahatkan tanah atau mengosongkan lahan, atau 1 bulan tidak ditanam apa-apa. Namun hal itu tidak diberlakukan untuk seluruh lahan. Misalnya dari 3 hektar lahan yang ada, ada 1-2 hektar lahan yang diistirahatkan tanahnya yaitu tidak ditanam apa-apa dulu. Gulma dan rumput dibiarkan tumbuh pasca panen. Hal ini dilakukan karena tanah itu ibarat jantungnya tanaman. Jika jantungnya sehat maka tanaman yang ditanam juga akan tumbuh dengan baik. Untuk rumput, para petani menyiangi rumput secara manual. Karena sistem ini produk tanaman oleh petani di Marpoyan Damai mendapatkan sertifikat Prima 3 yaitu komoditi tanaman yang aman dimakan dan bebas pestisida.

Berdasarkan hasil wawancara di Jalan Rawa Bening Kecamatan Tampan, diketahui bahwa bayam diproduksi setiap 20 hari. Bayam hasil produksi langsung dijual ke konsumen namun sebagian juga ada ke tengkulak. Bibit yang digunakan yaitu hasil pembibitan sendiri dan ada juga bibit bantuan dari pemerintah. Banyak bibit yang digunakan yaitu 15 sendok untuk ukurang beden 30x30. Jumlah pupuk yang digunakan yaitu 2-3 ton per Ha. Petani di di Jalan Rawa Bening Kecamatan Tampan jarang menggunakan insektisida, kalaupun pernah menggunakan herbisida merk Abos yang takarannya 1,5 liter per hektar, dimana herbisida tersebut dicairkan sebanyak $25 \mathrm{ml}$ per 15 liter air. Jumlah bayam yang dihasilkan dalam 1 bedengan bisa 500-600 ikat bayam dengan berat per ikat sekitar 1/4 $\mathrm{kg}$.

Tata cara menanam bayam yaitu awalnya tanah digemburkan, setelah itu diratakan, untuk ukuran bedengan yang digunakan yaitu $30 \times 3$ meter. Setelah diratakan diberi pupuk kandang dengan cara ditaburkan pupuknya lalu ditebar benih. Benih dicampurkan dengan tanah agar merata. Menjelang tumbuh akan dilakukan penyiraman 3 hari pertama berturut-turut sebanyak dua kali sehari yaitu pada pagi dan sore hari. Setelah bayam berumur 10 hari kemudian diberi pupuk urea dan pada umur 18 hari telah panen.

Petani menggunakan pestisida pada tanaman bayam tapi tidak rutin. Dalam setahun, petani menanam bayam sekitar 12-14 kali tanam. Biasanya, dilakukan rotasi atau pertukaran komoditi yang ditanam. Setelah menanam bayam, petani umumnya akan menanam terong, kacang panjang, timun, sawi dan labu. Kepemilikan lahan yaitu 1,5 hektar milik sendiri dan 1,5 hektar lagi milik orang lain yang dititipkan untuk dirawat, namun petani tidak dikenai biaya sewa lahan. Menurut petani, ada industri 
rumahan untuk hasil panen bayam, misalnya dibuat peyek bayam. Namun untuk pembuatan peyek bayam tidak bisa menggunakan bayam yang berumur 18 hari karena masih terlalu muda. Untuk membuat peyek bayam umumnya digunakan bayam yang berumur 40 hari karena daunnya sudah tua dan lebar. Selain itu bayam yang sudah berumur 40 hari tersebut juga sudah berbunga dan bisa dijadikan bibit atau benih.

Petani di Jalan Rawa Bening Kecamatan Tampan sudah pernah mendapatkan bantuan dari pemerintah yaitu pada tahun 2018 dari Kementerian Pertanian, berupa 1 paket bawang, sayuran dan buah berupa kacang panjang, tepong, pare, jagung dan juga pupuk kandang. Pada tahun 2019 para petani juga sudah mendapatkan bantuan dari Dinas Ketahanan Pangan yaitu 1 paket benih untuk sayuran daun lebar seperti bayam, sawi, seledri dan kangkung. Pada tahun 2020 belum ada bantuan yang didapatkan. Petani bayam di Jalan Rawa Bening Kecamatan Tampan pernah mendapatkan pelatihan dari dinas yaitu pelatihan teknologi organic dan hidroponik, pelatihan penanganan pasca panen untuk petani sayur di Kota Pekanbaru, serta pelatihan pembuatan pupuk organik cair dari urin sapi.

\section{Memformulasikan Strategi Usahatani Bayam (A. Tricolor L.) yang Berkelanjutan di Kota Pekanbaru}

Pengelolaan usahatani bayam di Kota Pekanbaru telah berjalan dengan baik, serta sudah ada efisiensi dalam penanaman dan dikatakan menguntungkan. Dari sisi ekologi yaitu luas lahan, jenis tanah, $\mathrm{pH}$ tanah dan kelembaban sudah sesuai dengan habitat yang baik untuk menanam bayam. Dari segi ekonomi, B/C yang diterima yaitu $>1$ sehingga usaha tani bayam di Kecamatan Marpoyan Damai dan di Kecamatan Tampan efisiensi dan menguntungkan untuk diusahakan. Berdasarkan analisa tersebut maka usaha tani bayam di Kota Pekanbaru menguntungkan dan layak untuk dikembangkan. Petani perlu mempertahankan dan meningkatkan usaha tani bayam ini.

Di Kecamatan Tampan, petani masih menggunakan insektisida untuk tanaman bayam walaupun tidak sering. Hal ini sebaiknya dihentikan guna mendapatkan sertifikasi prima satu.

Prima Satu (P-1) merupakan penilaian yang diberikan terhadap pelaksanaan usaha tani dimana produk yang dihasilkan aman dikonsumsi, bermutu baik, dan cara produksinya ramah terhadap lingkungan. Prima Dua (P-2) yaitu penilaian yang diberikan terhadap pelaksana usaha tani dimana produk yang dihasilkan aman dikonsumsi dan bermutu baik. Sedangkan Prima Tiga (P-3) adalah penilaian yang diberikan terhadap pelaksana usaha tani dimana produk yang dihasilkan aman di konsumsi.

Di Kecamatan Marpoyan Damai tidak dilakukan insektisida karena petani sudah menanam tanaman refugia sebagai cara alami pengendalian hama. Tanaman yang ditanam yaitu katuk (Sauropus androgynus), dimana 10 - 15 hari sebelum petani menanam bayam, petani sudah lebih dulu menanam tanaman katuk (Sauropus androgynus). Pada tanaman bayam, hama yang sering menempel adalah ulat daun dan kumbang, jadi dengan menanam daun katuk (Sauropus androgynus) sayur bayam tidak akan terkena hama lagi karena sudah ada tanaman lain yang menjadi tempat persinggahan serangga. Pemilihan daun katuk (Sauropus androgynus) karena selain ekonomis juga ramah lingkungan, perawatannya mudah serta mempunyai nilai komersil, sehingga petani juga bisa mendapatkan keuntungan dari memanen daun katuk (Sauropus androgynus). Hal ini juga sebaiknya diadaptasi oleh petani di Kecamatan Tampan sehingga produk pertanian yang dihasilkan bebas dari insektisida.

Komponen biaya tetap terbesar di Kecamatan Marpoyan Damai adalah biaya tenaga kerja. Adanya keterbatasan sumber daya petani membuat usahatani membutuhkan banyak tenaga kerja untuk memanen hasil pertanian. Berbeda dengan Kecamatan Marpoyan Damai, di Kecamatan Tampan pekerjaan para petani dilakukan dengan sistem gotong royong, sehingga para tenaga kerja dibayar dengan membagikan tanaman hasil panen. Pekerjaan pria adalah menggemburkan tanah, menanam, memupuk, menyiram dan menyemprot jika terdapat hama. Pekerjaan tenaga kerja wanita adalah memanen dan memasarkan. Namun demikian, kedua sistem tersebut sama-sama memberikan keuntungan dimana B/C ratio untuk Kecamatan Marpoyan Damai adalah 1,95 dan B/C ratio di Kecamatan Tampan adalah 2,07.

\section{KESIMPULAN}

Luas lahan untuk menanam bayam di Kecamatan Tampan seluas 3 hektar dan di Kecamatan Marpoyan Damai 3,5 hektar. Jenis tanah yang digunakan di Kecamatan Marpoyan Damai dan Kecamatan Tampan adalah tanah humus. $\mathrm{pH}$ tanah di Kecamatan Marpoyan Damai dan Kecamatan Tampan berkisar antara 5,5-6. Rata-rata curah hujan di Kota Pekanbaru adalah 170,7 dengan rata-rata lama hari hujan 14 hari setiap bulannya dan kelembaban di Kota Pekanbaru yaitu 70-85\%. Secara keseluruhan, dari sisi ekologi sudah sesuai dengan habitat yang baik untuk menanam bayam. Biaya yang dikeluarkan di Kecamatan Marpoyan Damai yaitu Rp 11.670.000 per hektar sedangkan di Kecamatan Tampan sebesar Rp 8.260.000 per hektar. Penerimaan kelompok usaha tani bayam di Kecamatan Marpoyan Damai yaitu Rp 22.800.000 dan di Kecamatan Tampan sebesar Rp 17.100.000. Pendapatan petani bayam di Kecamatan Marpoyan Damai yaitu sebesar Rp 11.130.000 dan di Kecamatan Tampan 
sebesar Rp 8.840.000. B/C ratio di Kecamatan Marpoyan Damai yaitu 1,95 dan di Kecamatan Tampan 2,07. Di Kecamatan Marpoyan Damai, pertanian bayam dilakukan oleh Kelompok Tani Suka Makmur, yaitu oleh Bapak Mudhofir yang berusia 39 tahun dengan pendidikan terakhir SMA. Konflik antar petani yang pernah terjadi yaitu masalah lahan dan telah diselesaikan secara kekeluargaan. Berdasarkan hasil wawancara di Jalan Rawa Bening Kecamatan Tampan, pertanian bayam dilakukan oleh Kelompok Tani Baskara Jati, yaitu oleh Bapak Topan yang berusia 51 tahun dengan pendidikan terakhir SMP. Konflik antar petani yang pernah terjadi yaitu selisih paham dan telah diselesaikan secara kekeluargaan.

\section{UCAPAN TERIMAKASIH}

Ucapan terima kasih penulis sampaikan kepada para petani di Kecamatan Marpoyan Damai dan Kecamatan Tampan yang telah memberikan data dan informasi tentang usaha tani bayam sehingga terlaksananya penelitian ini di lapangan.

\section{DAFTAR PUSTAKA}

Amanda, U.D. 2017. Pemanfaatan Tanaman Refugia untuk Mengendalikan Hama dan Penyakit Tanaman padi. Buletin Ikatan (Informasi Pengkajian dan Diseminasi Inovasi Teknologi Pertanian) Vol.7 No.2.

Bandini L dan Aziz, 2005. Bayam. Penebar Swadaya. Jakarta.

BPS. 2014. Kota Pekanbaru Dalam Angka. Pekanbaru.

Cahyadi, W. 2006.Analisis dan Aspek Kesehatan Bahan Tambahan Pangan. Bumi Aksara. Jakarta.

Darwis, Khaeriyah. 2017. Ilmu Usahatani, Teori dan Penerapan. CV. Inti Mediatama. Makassar.

Dewi, Pratica. 2015. Pendapatan Usahatani Bayam di Desa Ciaruteun Ilir Kecamatan Cibunglang Kabupaten Bogor Jawa Barat. Jurnal Forum Agribisnis Vol. 3 No.2.

Dharma, S. 2014. Analisa Usahatani Bayam. Jurnal Wahana Inovasi Vol. 3 No.1.

Fitri. 2007. Pemanfaatan Limbah Cair Kelapa Sawit (LCKS) untuk Pemupukan Tanaman Bayam Cabut (Amaranthus tricolor L.). Jurnal MIPA. Fakultas Matematika dan Ilmu Pengetahuan Alam.Universitas Riau, Pekanbaru

Firdaus, M. 2007. Manajemen Agribisnis. Bumi Aksara. Jakarta.

Harijati, S. 2007. Potensi dan Pengembangan Kompetensi Agribisnis Petani Berlahan Sempit : Kasus Petani Sayuran di Kota dan Pinggiran Jakarta dan Bandung. Repository IPB

Hutagulung, H.P. 1997. Metode Analisis Air Laut, Sedimen, dan Biota. Buku 2. PPPO-LIPI. Jakarta. 2: 80.

Irwan. 2002. Lingkungan Hidup dan Hayati dan Sistem Perladangan Daerah Kalaimantan Barat.Samodra Mas. Pontianak.

Kamisi, H.,L. 2013. Analisis Usahatani Bayam (Studi Kasus di Kelurahan Sasa Kecamatan Ternate). Jurnal Ilmiah Agribisnis dan Perikanan Vol. 6 No.1

Kartono, K. 1983. Patologi Sosial. CV Rajawali. Jakarta.

Kohar, I., P. H. Hardjo, dan I. L. Wijaya. 2005. Pencemaran Logam Berat. Jakarta. Jurnal Makara Sains. 9 (2): 56-59.

Khaeruddin. 1992. Kurikulum Tingkat Satuan Pendidikan: Konsep dan Implementasinya. Bumi Aksara. Jakarta.

Kholidiyah. 2010. Respon Biologis Tumbuhan Eceng Gondok (Eichorniacrassipes Solms) sebagai Biomonitoring Pencemaran Logam Berat $\mathrm{Cd}$ dan $\mathrm{Pb}$ pada Sungai Pembuangan Lumpur Lapindo, Kecamatan Porong, Kabupaten Siduarjo.Jurnal Sains.Jurusan Biologi. Fakultas Sains dan Teknologi. Universitas Islam Negeri (UIN) Maulana Malik Ibrahim, Malang.

Leeuwis, C. 2013. Komunikasi Untuk Inovasi Pedesaan; Berpikir Kembali tentang Penyuluhan Pertanian. Edisi ke-5. Kanisius. Yogyakarta.

Mardikanto, T. 1993. Penyuluhan Pembangunan Pertanian. Sebelas Maret. University Press. Surakarta. 


\section{ZONA}

Jurnal Lingkungan

ISSN : 2502-6496 (Print)
Volume 4, No 2, Oktober 2020, p. 67-77 http://zona.pelantarpress.co.id

Mardiningsih, T.L. 1997. Serangga Perusak Daun Katuk. Jurnal Warta Tumbuhan Obat Indonesia Vol.3 No.3.

Mosher, A.,1968. Getting Agriculture Moving. A/D/C.

Pakpahan, A. 1992. Penelitian tentang Ketahanan Pangan Masyarakat Berpendapatan Rendah. Pusat Penelitian Sosial Ekonomi Pertanian. Badan Penelitian dan Pengembangan Pertanian, Departemen Pertanian Republik Indonesia.

Pracaya, IR, 2007, Bertanam Sayuran Organik di Kebun, Pot \& Polibag, Penebar Swadaya, Jakarta

Purwono R. 2008. Budidaya Delapan Jenis Tanaman Pangan. Penerbit. Universitas Padjadjaran. Bandung.

Rahmat, M., Supriyati, D. Hidayat dan J. Situmorang. 2000. Perumusan Kebijaksanaan Nilai Tukar Petani dan Komoditas Pangan Pertanian. Laporan Hasil Penelitian. Badan Pusat Penelitian Sosial Ekonomi Pertanian. Departemen Pertanian. Bogor.

Rukmana, R. 1994. Bayam. Penerbit Kanisius. Jakarta.

Rosyidi, Suherman. 2009.Pengantar Teori Ekonomi . PT.Raja Persada.Jakarta

Soekartawi, 2002. Prinsip Dasar Ekonomi Pertanian. Teori dan Aplikasi.Raja Grafindo Persada, Jakarta.

Spencer. 1993. Competence at Work, Models For Superior.John Wiley \& Sons, Inc. Canada.

Suhardiyono, L. 1989. Penyuluhan: Petunjuk Bagi Penyuluh Pertanian. Erlangga. Jakarta.

Sunarjono, H. 2013. Bertanam 36 Jenis Sayur. Penebar Swadaya. Jakarta.

Suratiyah, K. 2015. Ilmu Usahatani. Penebar Swadaya. Jakarta.

Surbakti, R. 1992, Memahami Ilmu Politik, Gramedia Widya Sarana,. Jakarta.

Sutanto. 2002. Penerapan Pertanian Organik: Pemasyarakatan dan Pengembangannya. Penerbit Kanisius. Jakarta.

Steenis, VCGGJ. 2005. Flora untuk Sekolah di Indonesia. Pradya Paramita. Jakarta.

Tafajani. 2011. Panduan Komplit Bertanam Sayur dan Buah-buahan. Cahaya Atma.Yogyakarta. 